\title{
The bald-sea-urchin disease: a biopathological approach
}

\author{
P. Maes* \& M. Jangoux \\ Laboratoire de Biologie marine, Université Libre de Bruxelles; \\ B-1050 Brussels, Belgium
}

\begin{abstract}
Individuals of several species of European regular echinoids are affected by a spectacular disease that causes conspicuous lesions on the echinoid body surface. It is a communicable non-specific disease that produces loss of appendages and necrosis of dermal and skeletal tissues. Preliminary investigations indicate that the pathogen is not an alga but could be a bacteria.
\end{abstract}

\section{INTRODUCTION}

Disease-causing, conspicuous lesions on the outer body surface of several species of littoral regular echinoids were reported by Johnson (1971) and Pearse et al. (1977) along the coast of California and by Höbaus et al. (1981) in the Mediterranean Sea. The lesions are sometimes very extensive, and the disease may cause death of the echinoids. Mass mortalities were reported that consequently produce obvious changes in the surrounding environment (Pearse \& Hines, 1979; Boudouresque et al., 1980, 1981). This paper presents the symptomatology of the so-called 'bald-sea-urchin disease' and tentatively considers the nature of the pathogenic agent.

\section{MATERIALS AND METHODS}

Diseased individuals of the following species were collected either by hand at low tide or by SCUBA diving: Echinus esculentus and Sphaerechinus granularis (Pointe de l'Armorique, Brittany, France), Psammechinus miliaris (Luc-sur-mer, Normandy, France), Arbacia lixula and Paracentrotus lividus (Villefranche-sur-mer, South of France, and Monaco).

Experimental infections were performed in the laboratory. Healthy echinoids were slightly injured in an interambulacrum (i. e. scarification of the skin and removing of a few spines). Injured areas were then painted using pieces of necrotic tissues taken from lesions of diseased individuals. The development of the newly formed lesions was followed for several weeks, and the echinoid reactions were noted.

\footnotetext{
- Supported by an IRSIA grant
} 


\section{RESULTS AND DISCUSSION}

\section{Symptomatology}

Lesions are of various sizes, from a few $\mathrm{mm}^{2}$ to more than one third of the whole body surface. Several lesions may co-occur on a single echinoid. Whatever its size, a typical lesion always consists of an area entirely deprived of appendages (i. e. spines, pedicellariae, tube-feet), lined by a belt of swollen reddish tissue (Figs 1,3). The area inside the reddish belt may have two different aspects; it is covered by green-colored necrotic tissues (Figs 3,4 ) or consists only of denuded test skeleton, the superficial necrotic tissues being lost. In the latter case, the diseased body-wall area may be colonized by incrusting organisms (e.g. Mortensen \& Rosevinge, 1934).

Typical lesions may develop everywhere on the body surface. Ambulacral lesions are not wider than the interambulacral ones, and the tube feet outside the infected ambulacral areas often appear to be healthy. This would imply that the disease agent is not efficaciously transported through the water-vascular system (i.e. the radial canal). Some individuals may be infected only on a few spines. In such cases the distal part of the spines basically present the same symptoms as the affected parts of the body surface. Actually, each infested spine shows three superimposed circular areas, viz. a lower red area that corresponds to the reddish belt of the body wall lesions, a middle green ring made of necrotic epidermis, and an upper area consisting of denuded spine skeleton (Figs 5,6).

When naturally diseased echinoids are kept in an aquarium, their lesions sometimes extend suddenly. The superficial tissues of the newly infected areas rapidly become necrotic. A typical green color appears within 1 day, and the spines separate from the body surface in less than $48 \mathrm{~h}$. Lesion regrowths develop quite rapidly and stop very abruptly.

Lesions of experimentally infected echinoids develop much more slowly. They never extend beyond the painted injured areas. Superficial tissues become necrotic and take on a green color within 3 days (Fig. 2). During the next 2 months the necrotic tissues will progressively modify their shape and texture (from filamentous to friable: Figs 3 and 4 , respectively) to be finally eliminated from the diseased areas. The lesions therefore appear as areas covered by denuded skeleton. One or two months later the upper skeletal layer will be eliminated in turn, leaving a small depression on the echinoid body surface. These depressions will be covered by a newly formed epidermis ("repair tissue"), and spines and other appendages progressively will regenerate.

Dead individuals collected in the field - mostly Sphaerechinus granularis - sometimes have well-defined disease-produced traces on the test skeleton. These traces appear either as test areas that have a typical greenish color (Figs 7,8), or as test areas that are depressed or even perforated (Figs 9, 10). The green coloration of the skeleton from affected areas extends more or less deeply inside the ossicles. In most cases the green coloration is rather superficial and a deep green line occurs at the limit between

Figs 1-4. Aspects of experimentally induced lesions (Psammechinus miliaris; horizontal lines represent $2.5 \mathrm{~mm}$ ). 1: General view of a diseased individual. 2: A lesion one day after experimental infestation. 3-4: The same lesion three days (3) and two months (4) after infestation.

Figs 5-6. Enlarged views of naturally infected spines (Psammechinus miliaris; horizontal lines represent $2.5 \mathrm{~mm}$ ) 

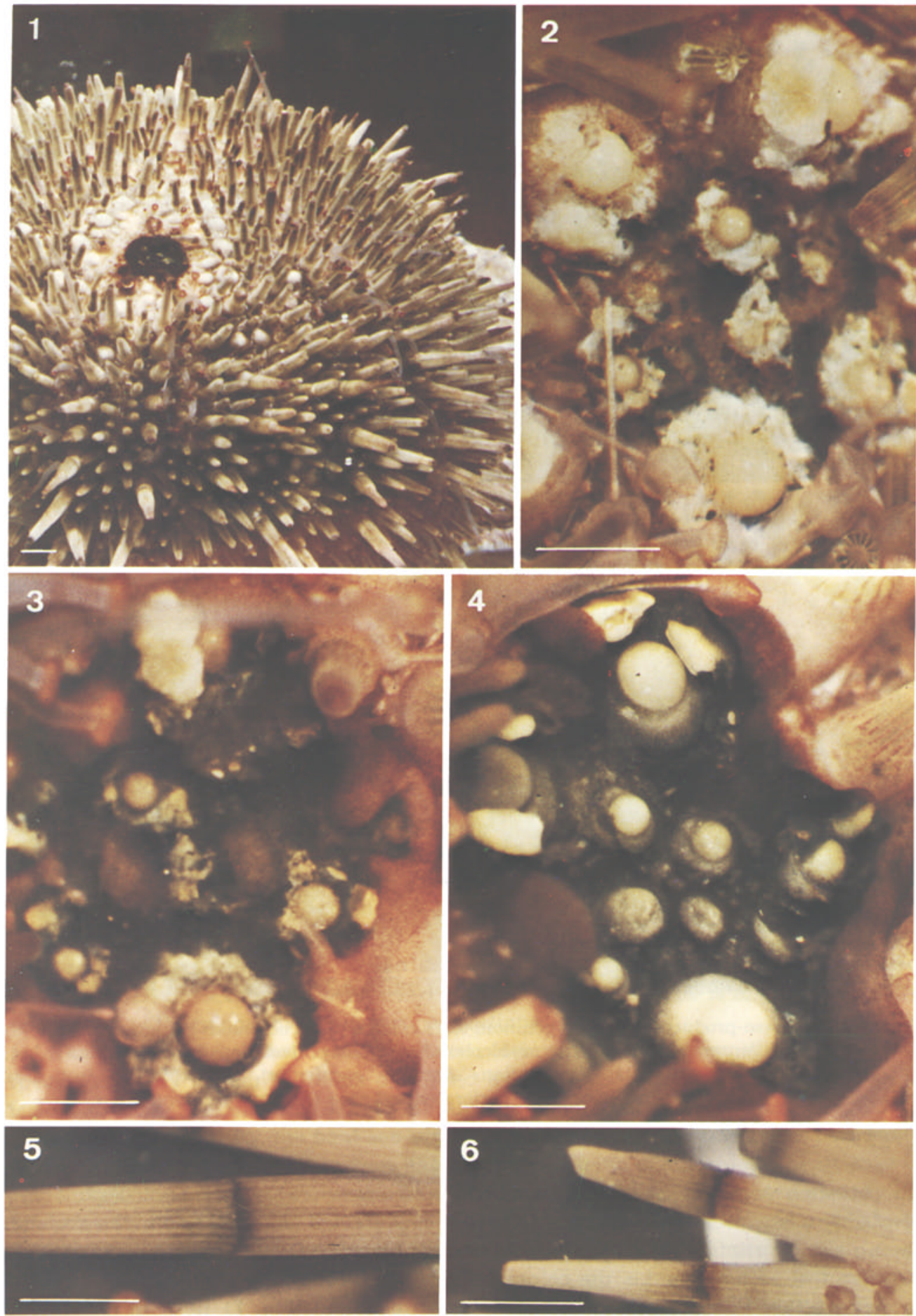

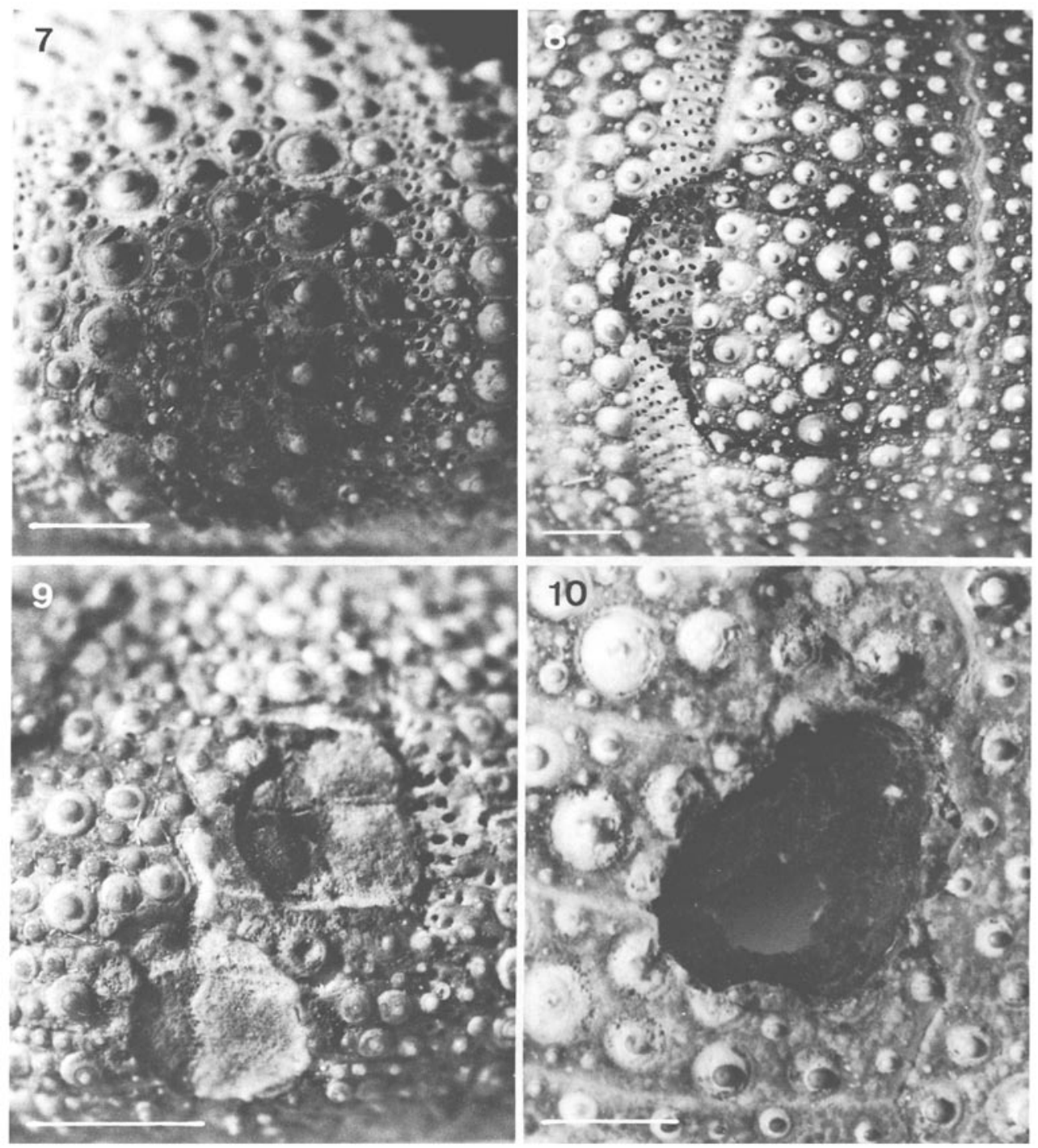

Figs 7-10. Disease-produced traces on echinoid test skeleton (dead echinoids collected in the field) (horizontal lines represent $5 \mathrm{~mm}$ ), 7 : greenish colored area (early infestation; Paracentrotus lividus). 8: greenish colored area (late infestation; Echinus esculentus). 9: depressed test area (Psammechinus miliaris). 10: perforated test area (Echinus esculentus)

the affected part and the healthy part of the skeleton (Fig. $11 \mathrm{~A}$ ). Such lesions may probably easily recover in living individuals, the affected (colored) part of the skeleton being simply eliminated (Fig. $11 \mathrm{D}$ ). Two other situations may occur that presumably involve test perforation, i.e. the coloration extends through the whole thickness of the ossicles either without presenting any deep green line (Fig. 11 B) or in developing 


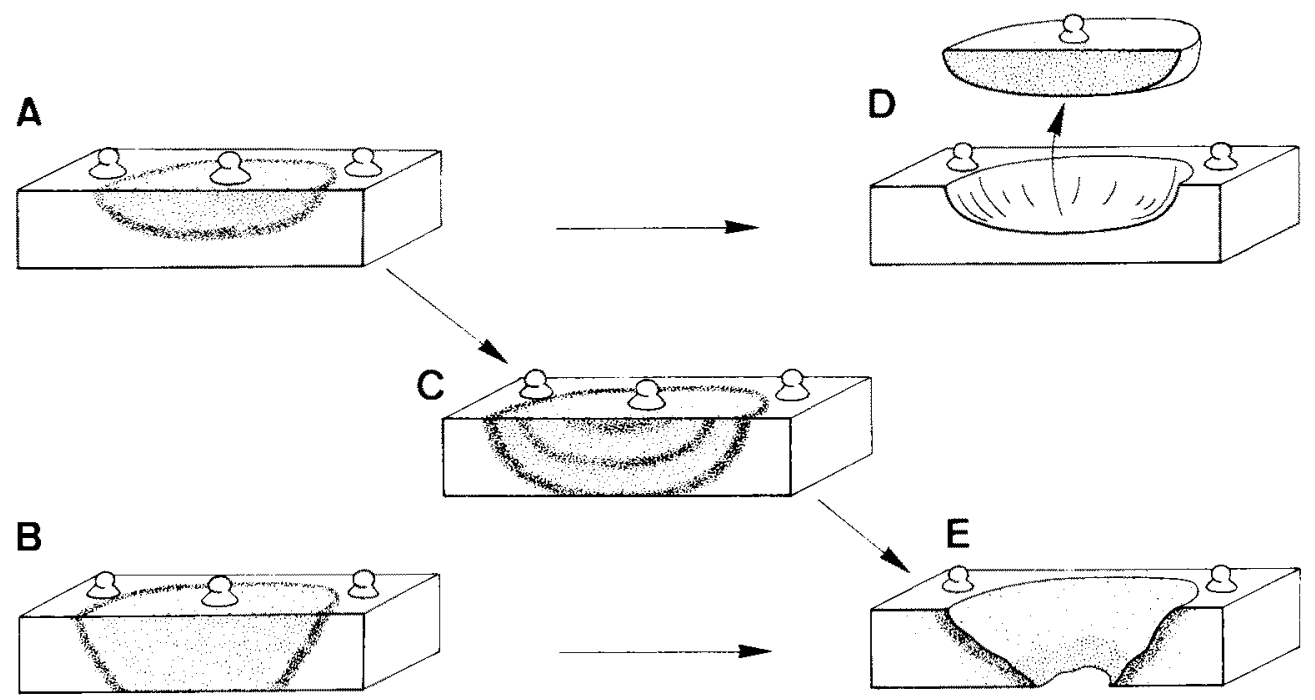

Fig. 11. Effects of the disease on the echinoid skeleton. A: superficial infestation. B \& C: lethal infestations. D: elimination of the affected skeletal layer (usually folowed by the echinoid recovery). E: perforation of the skeleton involving death of the echinoid

several concentric deep green lines (Fig. 11 C). This latter pattern suggests that a discontinuous development of the disease may occur.

Echinoids obviously react against the infection. Experimentally infested individuals develop an inflammatory-like reaction within 3 days, i.e. appearance around the diseased area of a conspicuous red belt that swells progressively. As already shown by Johnson (1971), that belt consists of a loose-agregate of cells presumably of coelomic origin, viz. phagocytic cells and red-spherule cells. When the affected area is small, the red belt progressively covers the lesion which in the end disappears. In contrast, when the affected area is large, the red belt extends within the test skeleton. Actually the belt tissue forms a kind of internal shield that isolates an upper layer of dead skeleton which finally is eliminated. Diseased echinoids thus are not defenceless, and can recover from the infection. Yet the bald-sea-urchin disease may be lethal and mass mortalities were reported (e.g. Pearse et al., 1977). In laboratory conditions, echinoid death occurred either with lesions extending over a very large area (more than $30 \%$ of the whole body surface), or with lesions involving test perforations.

The natural and experimentally induced lesions we observed on the investigated species are very similar to others described by previous authors (Table 1). All these lesions presumably concern a single disease the geographical distribution of which is rather peculiar. Actually, the bald-sea-urchin disease has been reported from both sides of the North Atlantic as well as from the Northeast Pacific (California). The disease is obviously not a recent phenomenon as very similar lesions were reported already by Mortensen \& Rosevinge (1934), and as Höbaus et al. (1981) noted, diseased individuals have been observed along the French Mediterranean coast for ca 20 years. 
Table 1. Records of the bald-sea-urchin disease

\begin{tabular}{|c|c|c|}
\hline Species & Geographical areas & References \\
\hline Arbacia lixula & $\begin{array}{l}\text { Western Mediterranean } \\
\text { (French coast) }\end{array}$ & $\begin{array}{l}\text { Höbaus et al. }(1981)_{i} \\
\text { this paper }\end{array}$ \\
\hline Cidaris cidaris & $\begin{array}{l}\text { Western Mediterranean } \\
\text { (French coast) }\end{array}$ & Fenaux (pers. comm.) \\
\hline Echinus acutus & North Sea (Norway) & Mortensen \& Rosevinge (1934) \\
\hline E. esculentus & N. E. Atlantic (Brittany, France) & this paper \\
\hline Paracentrotus lividus & $\begin{array}{l}\text { Western Mediterranean (Alicante, } \\
\text { Spain; French coast; S. Italy and } \\
\text { Sicily; Rijeka, Yogoslavia); N. E. } \\
\text { Atlantic (Brittany, France) }\end{array}$ & $\begin{array}{l}\text { Höbaus et al. (1981); } \\
\text { Boudouresque et al. (1980, } \\
\text { 1981); this paper }\end{array}$ \\
\hline Psammechinus miliaris & North Sea (Normandy, France) & this paper \\
\hline Sphaerechinus granularis & $\begin{array}{l}\text { Western Mediterranean (French } \\
\text { coast); N. E. Atlantic }\end{array}$ & $\begin{array}{l}\text { Höbaus et al. (1981); } \\
\text { this paper }\end{array}$ \\
\hline $\begin{array}{l}\text { Strongylocentrotus } \\
\text { droebachiensis }\end{array}$ & N. W. Atlantic (Nova Scotia) & $\begin{array}{l}\text { Miller \& Colodey (1983); } \\
\text { Scheibling (pers. comm.) }\end{array}$ \\
\hline S. franciscanus & N. E. Pacific (California) & $\begin{array}{l}\text { Johnson (1971); Pearse et al. } \\
\text { (1977); Pearse \& Hines (1979) }\end{array}$ \\
\hline S. purpuratus & N. E. Pacific (California) & Johnson (1971) \\
\hline
\end{tabular}

\section{Etiology}

The bald-sea-urchin disease is a communicable disease. Aquarium investigations demonstrated that necrotic tissues of affected individuals are infectious. Pieces of necrotic tissues cause the disease when painted on experimentally produced injuries of the outer body surface of healthy echinoids (Table 2). The painting of injured areas is not always necessary to infect echinoids. In some cases, the disease spontaneously develops when unaffected echinoids are placed simply in the vicinity of diseased individuals.

Table 2. Experimental infestation of healthy Psammechinus miliaris

\begin{tabular}{|lccc|}
\hline Experimental condition & $\begin{array}{c}\text { Number of } \\
\text { individuals } \\
\text { tested }\end{array}$ & $\begin{array}{c}\text { Number of } \\
\text { infected } \\
\text { individuals }\end{array}$ & $\begin{array}{c}\text { Number of } \\
\text { non-infected } \\
\text { individuals* }\end{array}$ \\
\hline $\begin{array}{l}\text { Injured healthy echinoids painted with } \\
\text { necrotic tissues } \\
\text { Injured healthy echinoids not painted with } \\
\text { necrotic tissues } \\
\text { (control experiments) }\end{array}$ & 23 & 23 & 0 \\
- Observations made three days after painting & 25 & 1 \\
\hline
\end{tabular}


Whatever the case, infection of echinoids maintained in laboratory conditions is possible only with individuals that have been previously injured.

The bald-sea-urchin disease is not specific. Using the scarification-paintingmethod, it is easy to infect echinoids of several different species. As shown in Table 3, the tests for interspecific infestations were all successful.

Table 3. Results of interspecific infestation

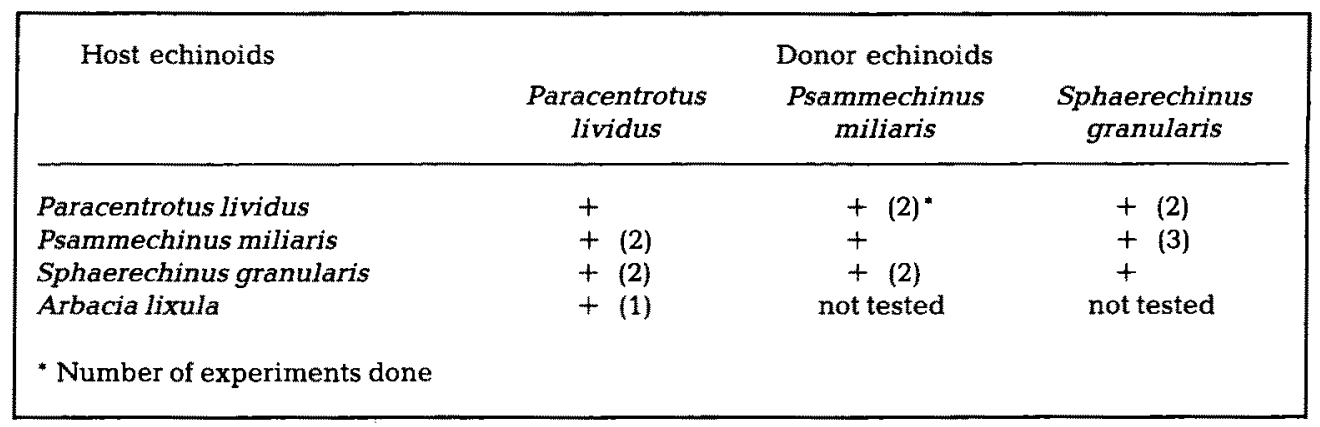

As for the nature of the pathogenic agent, it has been proven not to be an alga. Classical methods for extracting chlorophyll yielded no pigment (see also Johnson, 1971). This implies therefore that the pathogenic agent cannot be a bluegreen alga as suggested by Mortensen \& Rosevinge (1934). (Actually Mortensen \& Rosevinge reported that a blue-green alga was identified on smears made from necrotic tissues but that it was not recognized in histological sections.)

Preliminary histological and TEM investigations showed that numerous bacteria occur within the necrotic tissues while almost no protozoans and no fungi were seen. Experiments using penicillin antibiotics suggest that the pathogenic agent could be a bacteria. The experiments were done as follows: pieces of necrotic tissue were incubated for different periods of time in various concentrations of antibiotics in artificial sea water, control experiments being done with necrotic tissues incubated in artificial sea water. A $48 \mathrm{~h}$ incubation in penicillin $(200 \mathrm{IU} / \mathrm{ml})$ at $12^{\circ} \mathrm{C}$ clearly inhibited the development of the pathogen. Control experiments however showed that the experimental procedure itself strongly reduced the virulence of the pathogen. Actually, echinoids infected with tissue incubated in sea water developed only slight lesions that recovered within a few days, while those infected with freshly sampled tissue had conspicuous lesions that usually needed several months to recover. This could mean that the pathogen either is unable to survive or loses its infectiousness when pieces of infected tissues are separated from the echinoid. Further experiments are needed to determine the nature of the pathogenic agent, considering also the disease might be of viral origin.

Acknowledgements. We thank Dr. L. Fenaux for critical discussion; the Directors of the Marine Laboratory of Luc-sur-mer (Normandy, France), Roscoff (Brittany, France), and Villefranche-surmer (Côte d'Azur, France) for providing facilities; the "Fondation Albert 1er" (Monaco) for financial support. 


\section{LITERATURE CITED}

Boudouresque, C. F., Nedelec, H. \& Sheperd, S. A., 1980. The decline of a population of the sea urchin Paracentrotus lividus in the Bay of Port-Cros (Var, France). - Trav. scient. Parc natn, PortCros 6, 243-251.

Boudouresque, C. F., Nedelec, H. \& Sheperd, S. A., 1981. The decline of a population of the sea urchin Paracentrotus lividus in the Bay of Port-cros (Var, France). - Rapp. P.-v. Réun. Commn int. Explor. scient. Mer Méditerr. 27, 223-224.

Höbaus, H., Fenaux, L. \& Hignette, M., 1981. Premiéres observations sur les lésions provoquées par une maladie affectant le test des oursins en Méditerranée occidentale. - Rapp. P.-v. Réun. Commn int. Explor. scient. Mer Méditerr. 27, 221-222.

Johnson, P. T., 1971. Studies on diseased urchins from Point Loma. - A. Rep. Kelp Habit. Impr. Project Calif. Inst. Technol., Pasadena. 1970-1971, 82-90.

Miller, R. J. \& Colodey, A. G., 1983. Widespread mass mortalities of the green sea urchin in Nova Scotia, Canada. - Mar. Biol. 73, 263-267.

Mortensen, T. \& Rosevinge, L. K., 1934. Sur une algue cyanophycée, Dactylococcopsis echinin. sp., parasite dans un oursin. - Biol. Meddr 11 (7), 1-10.

Pearse, J. S., Costa, D. P., Yellin, M. B. \& Agegian, C. R., 1977. Localized mass mortality of red sea urchin, Strongylocentrotus franciscanus, near Santa Cruz, California. - Fish. Bull. U. S. 53, $645-648$.

Pearse, $_{\text {J }}$ J. S. \& Hines, A. H., 1979. Expansion of a central California kelp forest following the mass mortality of sea urchins. - Mar. Biol. 51, 83-91. 